\title{
Toxocariasis y vacunación para Toxocara: una revisión sistemática
}

\section{Toxocaríase e vacina para controle de Toxocara: uma revisão}

\author{
Dumar A. Jaramillo-Hernández ${ }^{1,2 *}, M V Z, E s p, M S c$; Luis F. Salazar-Garcés ${ }^{1}, B m, M S c, P h D$; \\ Mónica M. Baquero-Parra ${ }^{3}$, MV, MSc, PhD; Carina da Silva-Pinheiro ${ }^{1}, B, M S c, P h D ;$ \\ Neuza M. Alcantara-Neves ${ }^{1}, M D, M S c, P h D$
}

1 Instituto de Ciências da Saúde, Universidade Federal da Bahia, Salvador, Bahia, Brazil.

2 Escuela de Ciencias Animales, Facultad de Ciencias Agropecuarias y Recursos Naturales, Universidad de los Llanos, Villavicencio, Colombia.

3 Department of Pathobiology, Ontario Veterinary College, University of Guelph, Guelph, Ontario, Canada.

* Corresponding author's address: Laboratório de Alergia e Acarologia, Instituto de Ciências da Saúde, Universidade Federal da Bahia, Avenida Reitor Miguel Calmon, sem nº, Canela. CEP - 40110-100. Salvador, Bahia, Brazil. Email: dumar.jaramillo@unillanos.edu.co

\begin{abstract}
Based on prevalence and impact on public health, toxocariasis is an underestimated zoonosis in developing and developed countries. The transmission of Toxocara spp. involves pets, stray dogs and cats (Canis familiaris and Felis catus, respectively), which spread the parasite's eggs in their feces to the environment. One of the main risk factors for the infection and development of human toxocariasis, is to cohabit with puppies and kittens. For a long time, the preventive strategy for this parasitic infection has been the regular use of antiparasitic drugs to reduce parasite burden in the short term. A long lasting immunological protection can be achieved with vaccination, however, a vaccine is not yet available. Therefore, it is fundamental to know and to understand the state of the art of vaccine development for effective control of this zoonosis. This paper reviews the experimental studies focused on vaccine development for toxocariasis control, and special attention is given to relevant epidemiological studies on the importance of dogs in human toxocariasis.
\end{abstract}

Keywords: toxocariasis, immunoprophylaxis, immunotherapy, vaccine, zoonoses.

\section{Resumen}

Según la prevalencia y el impacto en la salud pública, la toxocariasis es una zoonosis subestimada en los países en desarrollo y desarrollados. La transmisión de Toxocara spp. involucra animales de compañía caninos y felinos, como también perros y gatos sin hogar (Canis familiaris y Felis catus, respectivamente), que diseminan los huevos del parásito en sus heces al medio ambiente. Uno de los principales factores de riesgo para la infección y el desarrollo de la toxocariasis humana es 
convivir con cachorros felinos y caninos. Durante mucho tiempo, la estrategia preventiva para esta infección parasitaria ha sido el uso regular de medicamentos antiparasitarios para reducir la carga parasitaria a corto plazo. Se puede lograr una protección inmunológica duradera con la vacunación, sin embargo, todavía no se dispone de una vacuna. Por lo tanto, es fundamental conocer y comprender el estado del arte del desarrollo de vacunas para el control efectivo de esta zoonosis. Este artículo revisa los estudios experimentales centrados en el desarrollo de vacunas para el control de la toxocariasis, y se presta especial atención a los estudios epidemiológicos relevantes sobre la importancia de los caninos domésticos en la toxocariasis humana.

Palabras clave: toxocariasis, inmunoprofilaxis, inmunoterapia, vacuna, zoonosis.

\section{Resumo}

Com base na prevalência e no impacto na saúde pública, a toxocaríase é uma zoonose subestimada nos países em desenvolvimento e desenvolvidos. A transmissão de Toxocara spp. envolve animais cães e gatos de estimação e vadios (Canis familiaris e Felis catus, respectivamente), que espalham os ovos do parasita nas fezes para o meio ambiente. Um dos principais fatores de risco para a infecção e desenvolvimento da toxocaríase humana é coabitar com filhotes de cachorros e gatos. Por um longo tempo, a estratégia preventiva para essa infecção parasitária tem sido o uso regular de medicamentos antiparasitários para reduzir a carga parasitária a curto prazo. Uma proteção imunológica duradoura pode ser alcançada com a vacinação, no entanto, uma vacina ainda não está disponível. Portanto, é fundamental conhecer e entender o estado da arte do desenvolvimento de vacinas para o controle efetivo dessa zoonose. Este artigo revisa os estudos experimentais focados no desenvolvimento de vacinas para o controle da toxocaríase, e atenção especial é dada a estudos epidemiológicos relevantes sobre a importância dos cães na toxocaríase humana.

Palavras-chave: toxocaríase, imunoprofilaxia, imunoterapia, vacina, zoonoses.

\section{Introduction}

The World Health Organization (WHO) estimates that in Latin America 100 out of every 100,000 people are affected by at least one parasitic zoonosis (WHO, 2017). Although their incidence and prevalence are high, zoonotic parasitosis such as toxocariasis, is among the five most neglected diseases in the world (CDC, 2014); and is generally associated with the presence of animals in human environments (Marques et al., 2012) respectively. The aim of this study was to assess the environmental contamination by Toxocara spp. eggs and hookworms (Ancylostoma spp.). Infection with Toxocara spp. occurs through the ingestion of embryonated eggs of Toxocara canis and T. cati eliminated by infected dogs and cats through their feces. Once the eggs reach the environment, they can infect a significant number of people, especially children, which increases the importance in public health to this parasitic disease (Jones et al., 2008).

Companion animals represent potential reservoirs for Toxocara spp. to minimize the possible zoonotic transmission, the Companion Animal Parasite Council -CAPC- recommends deworming 15 day old puppies until six months of age with a broad-spectrum antiparasitic drug (CAPC, 2016). This recommendation is based on the epidemiological principle of a $100 \%$ probability of parasitosis due to Toxocara spp. in puppies due to the transplacental transmission of $T$. canis and the high level of environmental contamination by embryonated eggs (Lucio-Forster et al., 2016).
The global importance of parasitic diseases affecting humans and domestic animals, and the emergence of drug resistance (Köhler, 2001; Kopp et al., 2009; Bowman, 2012) promote the need for research to control parasitoses in companion animals and to reduce the exposure risks to humans and the development of parasitic zoonotic diseases. The development of a vaccine to control toxocariasis in dogs will play a fundamental role in the global management of this disease (Gasser, 2013) and would strengthen conventional anti-parasitic management schemes. This very much depends on the characteristics of such vaccine, like the duration and protection level, shelf-life, storage conditions, transport and the population to protect (Han, 2015).

\section{Importance of toxocariasis in public health}

From the epidemiological and public health perspectives, toxocariasis is an underestimated zoonosis, with difficult diagnosis, present in developing and developed countries (Torgerson and Budke, 2006; Lucio-Forster et al., 2016). It is a chronic disease composed of polymorphic clinical pictures, such as visceral larva migrans syndrome (Beaver, 1962), ocular larva migrans syndrome (Schantz et al., 1979), neurotoxocariasis (Finsterer and Auer, 2007) and covert (or asymptomatic) toxocariasis (Taylor et al., 1987; Taylor et al., 1988). The causal agents of this zoonosis are ascaridid nematodes from the Toxocara genus: $T$. canis and $T$. 
cati mainly infecting domestic and stray dogs and cats (Overgaauw, 1997).

Toxocara genus is composed of several species and have a broad spectrum of definitive hosts and they are ubiquitous in urban, periurban and rural areas worldwide. There are other Toxocara species that require epidemiological studies to determine their impact on public health because they could occasionally be sources of infection for humans. The definitive hosts for T. vitolorum, are domestic and wild ruminants, which excrete larvae through milk, increasing the risk of infection, especially in rural areas of different countries where raw milk is ingested by people (Li et al., 2016). Another important species is T. pteropodis which is associated with bats and possible infection to domestic and synanthropic dogs (Prociv, 1989). It is believed that T. pteropodis is the causative agent of hepatitis-like disease in humans on Palm Island (Grenadines) (Moorhouse, 1982). In addition to these species T. tanuki, T. apodemi, T. lyncus, T. mackerrasae, T. paradoxura, T. sprenti and T. vajrasthirae, parasitize a variety of wildlife and synanthropic mammalians (such as bats and rodents, among others) (Gasser et al., 2006); in addition T. malaysense that has domestic and stray cats as definitive hosts (Le et al., 2016).

The female adult T. canis can oviposit up to 200,000 non-embryonated eggs daily which will be excreted through the feces of the host. These eggs develop to their infectious stage (embryonated eggs - containing stage 2 or 3 larvae, called L2-L3 infective larvae) in the environment (carpet, garden, soil, food) and/or in the fur of companion animals (Jones et al., 2008). The main risk factor associated with the development of human toxocariasis is to cohabit with companion animals (Wolfe and Wright, 2003), specifically puppies and kittens (Marmor et al., 1987; Lucio-forster et al., 2016). Puppies and kittens share interior resting areas with humans (bed, dining room, swimming pool, among others) (Scheibeck et al., 2011), creating a situation of great relevance in public health (Kollipara et al., 2016). Puppies can develop congenital parasitic infections due to the transplacental migration of these parasites while both, puppies and kittens, can be infected by ingestion of colostrum or breastmilk. These animals can become important disseminators of the nematode's eggs when having large parasite loads in their intestine (Bowman, 2014). Humans and several animals are considered paratenic hosts since the parasites larvae do not develop to the adults, but migrate through somatic tissues (i.e. muscle, eye, Central Nervous System -CNS) (Figure 1) where they persist as an infectious stage L3 for extended periods. The presence of larvae in these tissues induces various pathological changes according to their migratory capacity through tissues and the immune responses of the host (Strube et al., 2013), both situations addressed below.

The integral control of $T$. canis can be achieved by interrupting different stages of its life cycle (Figure 1). The main strategy is to deworm domestic dogs, giving special attention to pregnant bitches and puppies under 12 weeks of age. The implementation of massive deworming baits is useful to treat stray dogs. The challenge for the future is to establish vaccinations schemes to reduce and prevent the spread of eggs through feces into the environment (Hotez and Wilkins, 2009; Lee et al., 2014; Chen et al., 2018; Ma et al., 2018a).

The infection by $T$. canis is highly prevalent in the entire canine population that is not treated with anti-helmintics on a regular basis, and its presence in synanthropic and wild species makes its elimination almost impossible (Bowman, 2014). The high prevalence of toxocariasis can be explained by the hypobiosis of the parasite's larval stage (L2-L3); larval viability has been found nine years after larvae have been encysted in non-human primate tissues. Furthermore, in the murine model, active migration has been identified after larval hypobiosis (Beaver, 1962). Concerning human toxocariasis, studies about its prevalence have been done in countries of Africa, Asia, South America and specifically the United States, showing prevalence ranging from $5.1 \%$ up to $93 \%$ (Figure 2) (Buitrago and Gast-Galvis, 1965; Mendonça et al., 2012; Schoenardie et al., 2013; Macpherson, 2013; Cong et al., 2014; Moreira et al., 2014; Berrett et al., 2017; Sowemimo et al., 2017).

Deworming domestic dogs is one of the main strategies to control world-wide toxocariasis, based on the fact that a significant number of families have dogs and they are a source of dissemination of viable $T$. canis eggs through their feces (Alcantara-Neves et. al., 1989). Furthermore they may have L2-L3 in their coat (fur) (Holland, 2017). Thus playing a preponderant role as a risk factor for exposure and infection with $T$. canis in humans (Regis et al., 2011; Strube et al., 2013; Sowemimo et al., 2017). The prevalence of this infection in the canine population is found in figure 3 . The prevalence of canine toxocariasis ranges from $1.4 \%$ to $82.4 \%$ based on serodiagnosis and fecal exam. The real prevalence of canine toxorariasis is impossible to determine with the available information because most studies use different diagnostic methods, inclusion and excusion criteria; however, these studies are useful to show the epidemiological importance of canine toxocariasis in the world. 


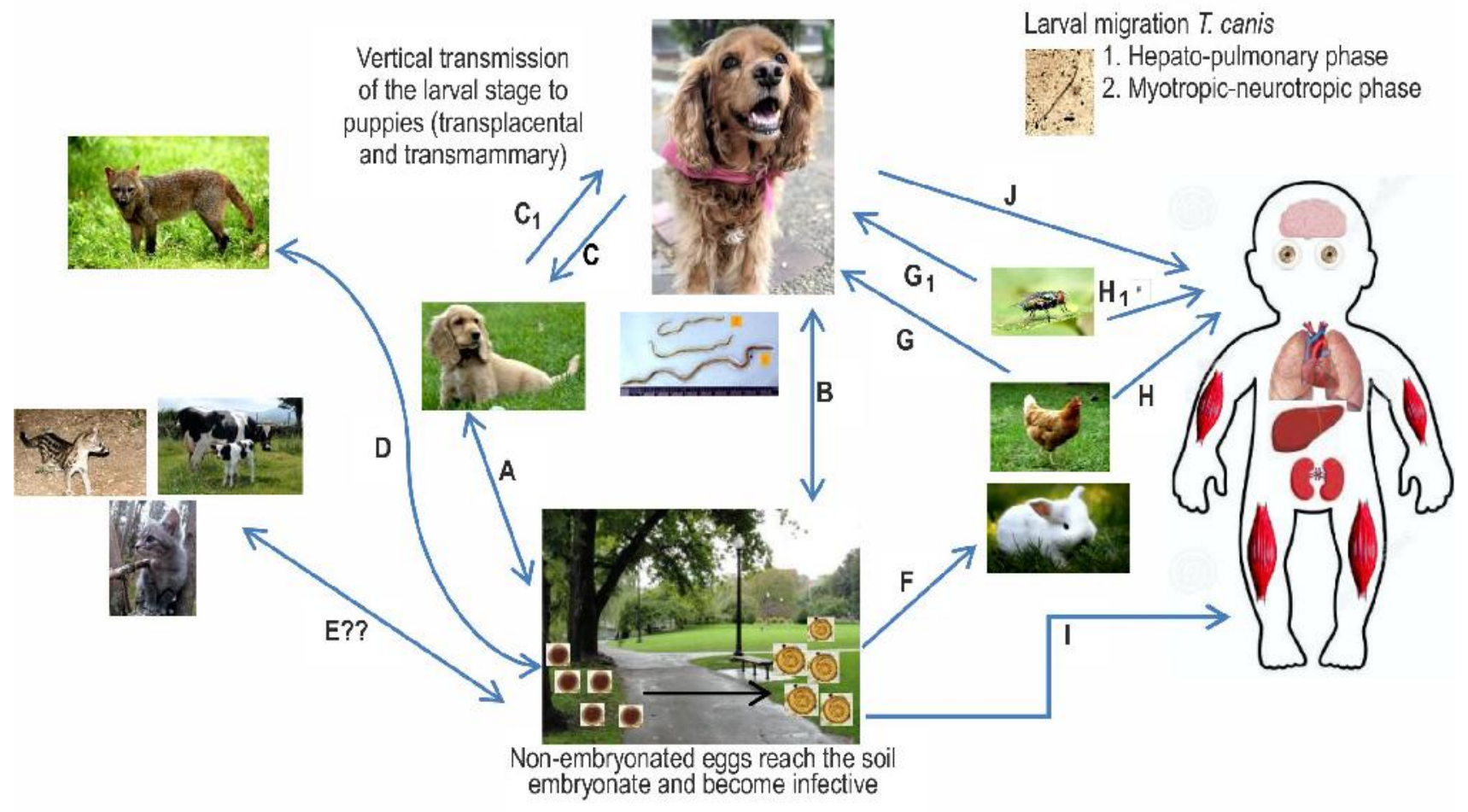

Figure 1. Biological cycle of Toxocara canis. A and B. Adult parasites are present in the intestine of domestic dogs (definitive host) which shed non-embryonated eggs through their feces. In the environment, they embryonate and become infective at temperatures of $25-30^{\circ} \mathrm{C}$ and a relative humidity of $85-95 \%$. The development of the larval infective stage (L2-L3) within the egg requires 9-15 days. The main route of infection with embryonated eggs is the oral route. In the intestine, L2-L3 hatch and penetrate the intestinal wall, taking different actions related to the age of the infected dog. In younger dogs, L2-L3 migrate through the liver, kidneys, lungs and trachea, and then are swallowed to reach the small intestine. Once in the lumen of the small intestine, the larvae develop to the fourth (L4) and fifth (L5) larval stages. Finally, they reach the adult stage when after differentiation into male or female, for subsequent oviposition by the females (prepatent period 4-5 weeks). In dogs older than three months of age, after oral exposure and initiation of migration through the enterohepatic circulation, L2-L3 tends to encyst in various tissues (i.e. liver, skeletal muscle) where they enter a state of hypobiosis. C. In pregnant bitches during the last third of pregnancy, hypobiotic larvae are activated through hormone receptors associated with pregnancy (i.e. prolactin, progesterone), thus developing vertical infection (transplancental) or transmammary infection to neonates. C1. A highly infected puppy can excrete L2-L3 in the emetic content and the bitch can get infected when cleaning the vomited material from the puppies. D. The parasite can also complete their life stage and spreading to the environment through synanthropic and wild canids. These definitive hosts may directly acquire the infection by consuming of embryonated eggs from the environment (i.e. water sources) or predating previously infected paratenic hosts. E. Other unconventional hosts (i.e. wild and domestic feline species) may be associated with the life cycle of $T$. canis and its spread in the environment, but more research is required to determine the certainty of their active participation in this process. F. T. canis can be accidentally transmitted to other paratenic hosts (i.e. poultry, rabbits), which may ingest embryonated eggs from the environment. In these paratenic hosts the larvae migrate and form tissue cysts. G. Domestic, synanthropic or wild canids can prey on an infected paratenic host. In this case, the infective tissue encysted larva will complete its life cycle in the predator's small intestine. G1 and H1. Occasionally, the infection can be transmitted by passive vectors such as synanthropic flies. $\mathrm{H}$. Humans are considered paratenic hosts and can become infected through the consumption of larvae from a paratenic host such as birds. I. The ingestion of embryonated eggs from the environment (e.g. geophagy). J. The dog's fur can be contaminated with embryonated eggs acquired from the environment, being a possible source of infection for humans. After egg ingestion they behave similarly as in the other paratenic hosts with two determined larval migration phases: 1. Hepato-pulmonary phase, and 2. Myotropic-neurotropic phase. Encysted hypobiotic larvae will induce granuloma formation as a result of the host's inflammatory response associated with the various toxocariasis syndromes. 


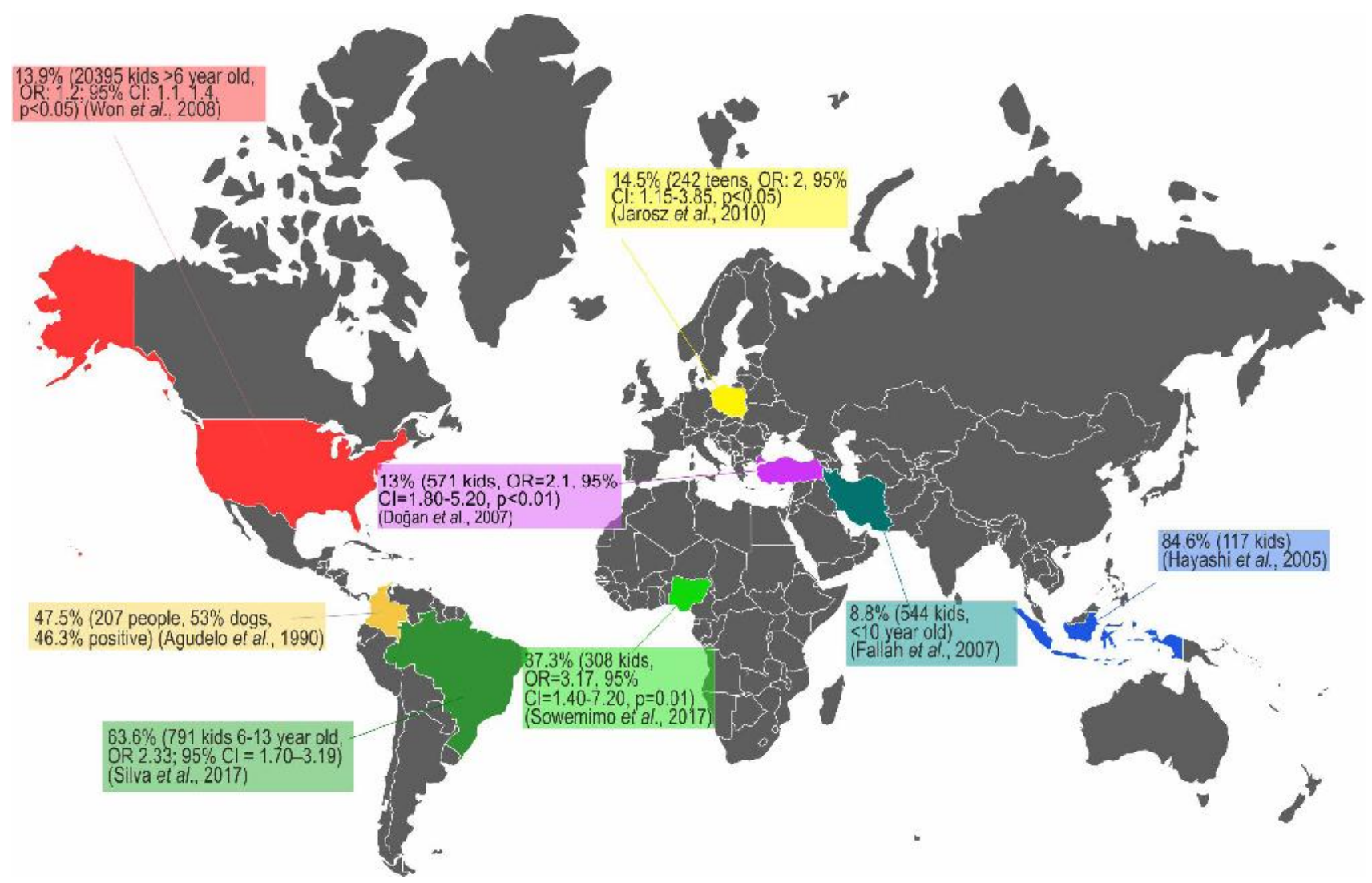

Figure 2. Several prevalence studies of T. canis infection in human population and epidemiological association with the presence of dogs. OR. Odds Ratio, Cl. Confidence Interval.

Moreover, other research has confirmed the importance of dogs in the dissemination of $T$. canis through their fur. In Ireland, Wolfe and Wright (2003) found that $15 / 60$ dogs had viable eggs in their fur, where approximately $4.2 \%$ of these eggs were embryonated and $23.9 \%$ in the embryonation process. This study found 20 embryonated eggs/gram of dog hair. Roddie et al., (2008) examined the fur of 100 dogs, finding $67 \%$ of samples contaminated with viable $T$. canis eggs. Another study found $21.56 \%$ of viable eggs on the fur of 51 dogs, in which $21 \%$ of those viable eggs were embryonated or in embryonation process, with an average fur contamination of 8.45 embryonated eggs/gram of dog hair (Aydenizöz Ozkayhan et al., 2008). Furthermore, a recent study with a sample of 100 dogs, found that $14 \%$ of the samples were contaminated with viable eggs, with an average of 136 eggs per sample (Öge et al., 2014). In Brazil, Merigueti et al., (2017) reported a presence of $6.67 \%$ fur contaminated with $T$. canis eggs in a sample of 165 dogs, with an average of 12.2 embryonated eggs/gram of dog hair.
Most of $T$. canis infections are asymptomatic; even though, the parasite triggers the host's immune response. Nematodes can exert the host's immune responses to preserve its parasitic capacity. Shiny et al., (2011) reported high levels of regulatory/anti-inflammatory cytokines such as IL-10 and TGF- $\beta$ between Wolbachia symbiotic phenomena with filariasis. Layland et al., (2013) found a significant recruitment of regulatory $\mathrm{T}$ cells $\mathrm{CD}^{+}{ }^{+} \mathrm{Foxp}^{+}$and the suppression of airway inflammation in a model of allergy in Schistosoma mansoni infected mice. Likewise Du et al., (2014) demonstrated that the excreted-secreted antigens from the Trichinella spiralis nematode inhibited the production of pro-inflammatory cytokines from classically activated macrophages $\left(M_{1}\right)$. The gastrointestinal nematode Trichuris muris can share epitopes of IFN- $\gamma$ in the murine model, thus modulating chronic infectious processes by inducing changes in lymphoid cells (Grencis and Entwistle, 1997). In the same experimental model, it was shown that some secreted proteins of T. muris bind to Toll-like receptor 4 (TLR4), activating MyD88 (essential part of middosome in the activation of inflamassome), downregulating $\mathrm{Th}_{2}$ 


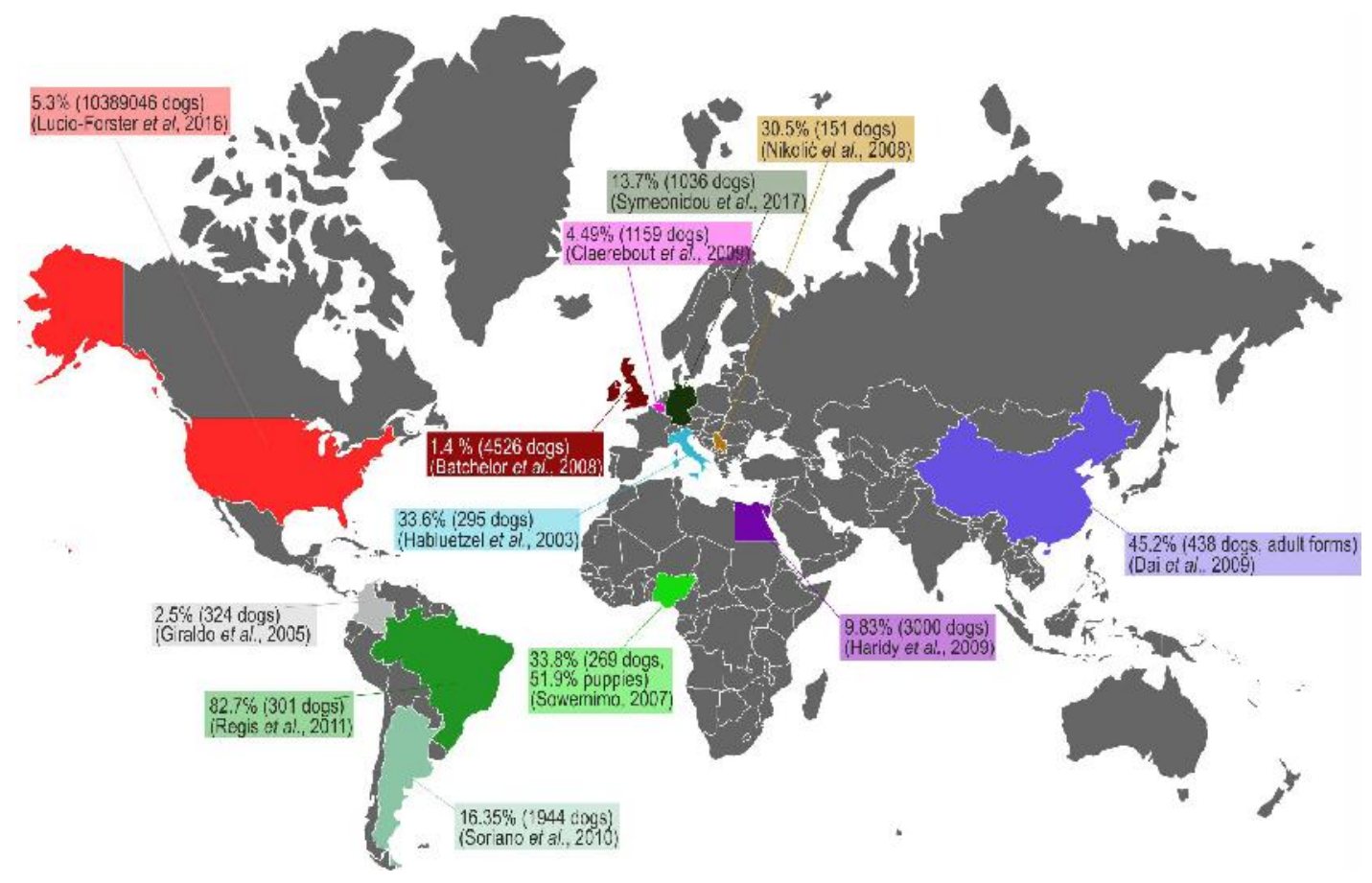

Figure 3. Several prevalence studies of T. canis infection in canine populations.

responses and allowing chronic infection (Helmby and Grencis, 2003).

Specifically, for T. canis infection in children, a positive correlation was found between eosinophilia, IgE and slgE levels (IgE specific for aeroallergens); a decreased cutaneous hypersensitivity for aeroallergens (Mendonça et al., 2012) and increased IL-10 production by blood cells (Alcantara-Neves et al., 2014). These conditions are the result of the interactions of $T$. canis and its hosts, altering the response to vaccination in children and predisposing to co-infections (Maizels and Mcsorley, 2016; Santos et al., 2017). Cooper et al., (2001) showed the potential modulation of immune responses by geohelminth like A. lumbricoides. After vaccination against cholera, the immune responses were effective in children that were treated with albendazol compared with children that received a placebo. On the other hand, significant interference has also been reported in antibody titration of puppies previously diagnosed with toxocariasis after receiving the rabies vaccine (Mojžišová et al., 2007).

\section{Immune responses to infection with $T$. canis and creation of vaccines for the control of toxocariasis}

Host immune responses to gastrointestinal helminth infection in general, cause a Th2-type immune response that in most cases make the host susceptible to reinfec- tion (Hewitson et al., 2009). The acute inflammatory reaction is the result mainly of the innate immunity to the excreted-secreted antigens of the infective T. canis larvae (TES), which include more than 50 different macromolecules represented by a relatively simple set of glycoproteins, consisting of three gene families: 1) mucins (high molecular weight glycosylated proteins, between 120 and 40-45 kDa); 2) C-type lectins (sugarbound proteins, whose molecular weights are around 70 and $32 \mathrm{kDa}$ ) (Maizels, 2006) and 3) other proteins that vary between 26 and $55 \mathrm{kDa}$ (Maizels and Loukas, 2001). Mucins vary in number and volume (Loukas et al., 2000a) which are strongly glycosylated with galactose linked to $\mathrm{O}$ - and $\mathrm{N}$-acetylgalactosamine groups (Meghji and Maizels, 1984). Apparently, this glycosylation capacity is related to the $\mathrm{Th}_{2}$ immune response and these molecules are specific targets for IgM (Schabussova et al., 2007). Furthermore, the larvae of $T$. canis periodically change their cuticle, releasing macromolecules to the host's blood circulation, hindering the action of specific anti-Toxocara antibodies which do not affect the parasite. This biological action is one of the forms of evasion of the host immune response and survival of this nematode inside their hosts' bodies (Loukas et al., 2000b; Schabussova et al., 2007).

TES and somatic antigens, from the worm surface (hidden antigens) when used as vaccine, can bind to pattern recognition receptors (PRRs) such as TLRs and C-type lectin Receptors (CTLs) expressed on the cell 
membrane of enterocytes and other cells exposed to these TES and somatic antigens (SA) during migration and larval development (i.e. dendritic cells -DCs, macrophages) (Van Kooyk and Geijtenbeek, 2003). After binding with TLRs and CLRs, intracellularly, the middosome (MyD88, IRAK4 and IRAK2) activates the signatosome (IKKY, IKK $\alpha$ and IKK $\beta)$ and via nuclear factor NF-KB activates the inflammasome (e.i. NLRP3) and causes the production of the proinflammatory cytokines IL-1 $\beta$ and IL-18 (Gordon, 2002). There is also recruitment of various leukocytes such as neutrophils, monocytes, eosinophils, $\mathrm{CD} 8^{+} \mathrm{T}$ cells, basophils and DCs, the latter being in charge of antigen presentation and beginning of the adaptive immune response. Likewise, a Th2 type response characterized by the secretion of cytokines such as IL-4, IL-5 and IL-13 from $\mathrm{CD}^{+} \mathrm{T}$ cells and innate lymphoid cells (Smith et al., 2012). Particularly, IL-4 promotes the differentiation of $\mathrm{B}$ cells and antibody class-switching. In addition, IL-5 promotes the differentiation of eosinophils, and eosinophilia is a notable characteristic of Toxocara spp. infection (Beaver, 1962; Neill et al., 2010).

It is essential to establish integrated control guidelines (Magnaval et al., 2001), in which vaccination to control this parasitic disease in dogs would be the main action against the infection in several paratenic hosts including humans (Despommier, 2003; Gasser, 2013; Maizels, 2013). The development of vaccines for control and prevention of diseases caused by nematode has been restricted, and only some studies have shown positive results (González-Hernández et al., 2016). As example, the protection that can be induced with natural antigens derived from the intestine of Haemonchus contortus, an important gastrointestinal nematode affecting sheep and goats (Newton and Munn, 1999). However, other parasites present greater challenges for the identification of vaccine candidate proteins (Hewitson and Maizels, 2014). An important obstacle, even with successful natural antigens, has been the development of effective synthetic or recombinant vaccines. Gauci et al., (2008) successfully tested recombinant antigens identified in Taenia multiceps, a worm in sheep, where its oncosphere antigens associated with the Quil $A^{\circledR}$ adjuvant significantly decreased the central nervous system parasite cysts. From immunoproteomic studies of Teladorsagia circumcincta, a gastrointestinal nematode of small ruminants, eight recombinant proteins were obtained and combined with the adjuvant Quil ${ }^{\circledR}$, getting $90 \%$ drop in fecal egg count for more than a year, and significant post-mortem reduction in the adult count in the gastrointestinal tract (Nisbet et al., 2013). These are some examples of success in the development of recombinant protein antigens for the control of gastrointestinal parasites. The limitation in the efficient development of vaccines against parasitic agents may be associated with the key roles that co-evolution and adaptation have played in the host-parasite relationship (Smith and Zarlenga, 2006). The different studies performed until now to evaluate vaccine proposals for the control of toxocariasis are summarized in Table 1, starting from the processes where embryonated parasite eggs exposed to ultraviolet radiation were used as the first approach to experimentation in dogs.

\section{Reverse vaccinology and new generation adjuvants as a strategy for vaccine development in the control of $T$. canis infection}

Advances in development computational software and discoveries of molecular functionality in modern biology have provided important opportunities to investigate epidemiological, diagnosis and even prophylaxy of Toxocara spp. (Ma et al., 2019). The clearest example of these applied cognitive development processes refers to genomic technologies of this parasite (Mardis, 2008, Ma et al., 2018b). The principle of reverse vaccinology starts from the genome sequence of the pathogen of interest and bioinformatics analysis, predicting those antigens that could be good candidates vaccine development, without the need to grow the specific organism to obtain natural antigens. The genome sequence provides a catalogue of virtually all proteic antigens that the pathogen eventually expresses. Furthermore, it is possible to generate new antigens (such as chimeric molecules), establishing new paradigms in immunodiagnosis or immunoprophylaxis for the infectious diseases control (Rappuoli, 2000; Mora et al., 2003; Sette and Rappuoli, 2010; Del Tordello et al., 2017).

There are several online databases for different important human and animal parasites (i.e. NEMBASE http://www.nematodes.org/nembase4, Nematode.net http://nematode.net, WormBase ParaSite http://parasite.wormbase.org/) that may be useful in the development of reverse vaccinology. In the case of $T$. canis the crucial point for the development of studies at this level is the completion of the $T$. canis genome project, in which Zhu et al., (2015) reported a genome size of 317 Mb. Recent studies led by Zhou et al., (2017) explored the details about the molecular biological processes of this nematode using high-performance transcriptomic sequencing of the 18,596 genes of the adult $T$. canis and bioinformatic analysis to explore aspects of reproduction and biological development of this parasite. Sperotto et al., (2017) developed the proteomic 
Table 1. Overview of published investigations of vaccine candidates and adjuvant for the control of toxocariasis

\begin{tabular}{|c|c|c|c|}
\hline $\begin{array}{l}\text { Experimental } \\
\text { model }\end{array}$ & Experimental vaccine/adjuvant & Result & Ref. \\
\hline $\begin{array}{l}\text { Albino mice, } \\
\text { Yale Swiss strain. }\end{array}$ & $\begin{array}{l}1 \text { mg (first doses) and } 2 \text { mg } \\
\text { (second doses) of T. canis: } \\
\text { A) Embryonated eggs extract }+ \\
\text { Freund's complete adjuvant (FCA) } \\
\text { B) Adult extract + FCA } \\
\text { C) Adult extract supernatant + FCA }\end{array}$ & $\begin{array}{l}\text { Found to harbor significantly fewer larvae } \\
\text { postmortem tissues after a challenge } \\
\text { infection than did controls in the A and C } \\
\text { groups ( } p<0.05 \text { ) and B group }(p<0.001) \text {. }\end{array}$ & $\begin{array}{l}\text { (Izzat and } \\
\text { Olson, 1970) }\end{array}$ \\
\hline CBA mice & TES T. canis $(1 \mu \mathrm{g})+\mathrm{FCA}$ & $\begin{array}{l}\text { Brain larvae recovery after } 6 \text { weeks of } \\
\text { immunization } 47.8 \pm 25.2 \text { Vs control group } \\
107.8 \pm 24.1 \text { ( } p<0.05 \text {, Wilconxon test). }\end{array}$ & $\begin{array}{l}\text { (Nicholas, } \\
\text { et al., 1984) }\end{array}$ \\
\hline BALB/cJ mice & $\begin{array}{l}\text { - Soluble extracts of embryonated } \\
\text { eggs and adult extract of T. canis, } \\
1.2 \mathrm{mg} \text { IP (first dose) and } 200 \mu \mathrm{g} \\
\text { IM (second dose). } \\
\text { - Cell } 2 \times 106 \text { IP or } 0.125 \mathrm{~mL} \text { of } \\
\text { serum/15 g BW (from mice } \\
\text { infected with T. canis). }\end{array}$ & $\begin{array}{l}\text { There was no significant difference in the } \\
\text { larvae found in the different organs of the } \\
\text { animals inoculated with the extracts of } \\
T \text {. canis. The group of animals inoculated } \\
\text { with cells and blood serum from animals } \\
\text { previously infected with } T \text {. canis (transfer of } \\
\text { resistance) produced a significant decrease } \\
(p<0.05) \text { in total observed larvae. }\end{array}$ & $\begin{array}{l}\text { (Concepcion, } \\
\text { and Barriga, } \\
1985 \text { ) }\end{array}$ \\
\hline Mice & $\begin{array}{l}\text { X-ray }(0-320 \mathrm{Krad}) \text { or of } \\
\text { gamma ray }(0-6 \mathrm{Mrad}) \\
\text { irradiated eggs containing } \\
\text { second-stage } T \text {. canis larva. }\end{array}$ & $\begin{array}{l}\text { No visceral larval migration was observed in } \\
\text { mice inoculated with } 1 \text { Mrad-irradiated eggs. }\end{array}$ & $\begin{array}{l}\text { (Kamiya } \\
\text { et al., 1987) }\end{array}$ \\
\hline Mice & $\begin{array}{l}\text { Embryonated eggs } T \text {. canis } \\
\text { extract + LPS E. coli o + FCA }\end{array}$ & $\begin{array}{l}\text { Reduction in the number of larvae } \\
\text { obtained post-mortem, extract } 36 \% \text {, LPS } \\
\text { + extract } 70 \% \text { and extract + FCA } 66 \% \text {. }\end{array}$ & (Barriga, 1988) \\
\hline $\begin{array}{l}\mathrm{NIH} \text { and } \\
\mathrm{CD} 1 \text { mice }\end{array}$ & $\begin{array}{l}\text { - Irradiated embryonated eggs UV } \\
\text { (350 nm) } 400 \text { eggs T. canis PO } \\
\text { - TES T. canis (8 mg IP) }\end{array}$ & $\begin{array}{l}24 \% \text { fewer larvae obtained post-mortem } \\
\text { in organs such as brain and muscle, } \\
\text { but retained in the liver }(\mathrm{p}<0.05) \text {. }\end{array}$ & $\begin{array}{l}\text { (Abo-Shehada } \\
\text { et al., 1991) }\end{array}$ \\
\hline $\begin{array}{l}\text { Outbred strain } \\
\text { of white mice }\end{array}$ & $\begin{array}{l}\text { - Eggs contain (PO), Adult extract, } \\
\text { adult TES, larval extract, larval TES } \\
\text { and perienteric fliud from adult } \\
\text { (SC - IM) of T. vitolorum. }\end{array}$ & $\begin{array}{l}\text { Significant reduction }(\mathrm{p}<0.001) \text { of the } \\
\text { number of larvae observed in different } \\
\text { tissues with perienteric fluid from adults } \\
\text { (100\% protection) and TES from infective } \\
\text { larvae (>92\% protection) of T. vitulorum. }\end{array}$ & $\begin{array}{l}\text { (Amerasinghe } \\
\text { et al., 1992) }\end{array}$ \\
\hline $\begin{array}{l}\text { IL-5 transgenic } \\
\text { mice }(\mathrm{Tg}) \text { and } \\
\text { no transgenic } \\
\text { mice } \mathrm{C} 3 \mathrm{H} / \mathrm{HeN}\end{array}$ & TES T. canis $(10 \mathrm{mg})+\mathrm{FCA}$ & $\begin{aligned} \text { - } & \text { Absorbance }(492 \mu \mathrm{m}) \text { IgG, vaccinated } \\
& \text { group Tg } 0.8 \text { and } \mathrm{C} 3 \mathrm{H} / \mathrm{HeN} 0.9 \text { Vs control } \\
& \text { group Tg } 0.15 \text { and } \mathrm{C} 3 \mathrm{H} / \mathrm{HeN} 0.14 \text {. } \\
\text { - } & \text { Counting of eosinophils, vaccinated group } \\
& 8100 \pm 1600 / \mathrm{mm} 3 \mathrm{Vs} \text { no vaccinated group } \\
& 7900 \pm 1200 / \mathrm{mm} 3 . \\
\text { - } & \text { Number of post-mortem larvae without } \\
& \text { significant differences }(\mathrm{p}>0.05) .\end{aligned}$ & $\begin{array}{l}\text { (Sugane } \\
\text { et al., 1996) }\end{array}$ \\
\hline Mice & $\begin{array}{l}\text { Glucan adjuvant }(0.5 \mathrm{mg} / \\
\mathrm{Kg} \mathrm{IM})+\mathrm{Ig}+\mathrm{Zn}\end{array}$ & $\begin{array}{l}\text { Marked cell proliferation, important level } \\
\text { of circulating anti-Toxocara antibodies and } \\
\text { notorious decrease of larvae } T \text {. canis obtained } \\
\text { post-mortem from the muscle and brain. }\end{array}$ & $\begin{array}{l}\text { (Soltys } \\
\text { et al., 1996) }\end{array}$ \\
\hline ICR mice & $\begin{array}{l}\text { T. canis eggs exposed ozone } 5.91 \\
\text { and } 6.76 \mathrm{mg} / \mathrm{L} \text { ( } 2000 \text { eggs PO) }\end{array}$ & $\begin{array}{l}\text { No significant difference in the number } \\
\text { of larvae recovered between ozone } \\
\text { treated and no-treated groups. }\end{array}$ & $\begin{array}{l}\text { (Ooi et al., } \\
1997)\end{array}$ \\
\hline
\end{tabular}




\begin{tabular}{|c|c|c|c|}
\hline $\begin{array}{l}\text { Experimental } \\
\text { model }\end{array}$ & Experimental vaccine/adjuvant & Result & Ref. \\
\hline C57BL6 mice & $\begin{array}{l}\text { Muramyldipeptide } \\
\text { Adjuvant } 4 \mathrm{mg} / \mathrm{Kg} \text { IP }\end{array}$ & $\begin{array}{l}\text { Stimulation of the phagocytic activity of } \\
\text { PMN, metabolic activity of macrophages and } \\
\text { lymphocyte proliferation. Reduction in } 30.6 \% \\
\text { of larval } T \text {. canis migration to different organs. }\end{array}$ & $\begin{array}{l}\text { (Dvoroznáková } \\
\text { et al., 1999) }\end{array}$ \\
\hline C57BL6 mice & $\begin{array}{l}\text { - TES T. canis }(30 \mu \mathrm{g})+\text { Freund's } \\
\text { Incomplete Adjuvant (FIA) }\end{array}$ & $\begin{array}{l}\text { When comparing the immunized } \\
\text { group Vs control group } \\
\text { - Greater proliferative response of } \mathrm{T} \text { and } \mathrm{B} \\
\text { lymphocytes }(\mathrm{p}<0.01) \text {. } \\
\text { - Lower number of CD8 }{ }^{+} \text {and } \mathrm{CD}^{+} \\
\text {lymphocytes }(\mathrm{p}<0.01) \text {. } \\
\text { - Higher concentration of IgG1 and IgG2. }\end{array}$ & $\begin{array}{l}\text { (Dvorožňáková } \\
\text { et al., 2000) }\end{array}$ \\
\hline C57BL6 mice & $\begin{array}{l}\text { - TES T. canis } 32,55,70 \text { and } 120 \\
\text { kDa }(30 \mu g)+\text { FIA } \\
\text { - Somatic antigen }\end{array}$ & $\begin{array}{l}\text { Protective effect of } 52.1 \% \text { in brain migration } \\
\text { and } 29 \% \text { in skeletal striated muscle tissue. }\end{array}$ & $\begin{array}{l}\text { (Dvorožňáko } \\
\text { et al., 2002) }\end{array}$ \\
\hline BALB/c mice & $\begin{array}{l}\text { DNA vector plasmid (pcDNA3- } \\
\text { CpG) and Plasmid expressing } \\
\text { murine IL-12 (pcDNA-IL-12) (1 } \mu \mathrm{g}) \\
+ \text { adjuvant micro particles of gold } \\
(1.5 \mu \mathrm{m}) . \text { Percutaneous route. }\end{array}$ & $\begin{array}{l}\text { - pcDNA-IL-12 group presented less } \\
\text { eosinophilic persistence in blood, broncho- } \\
\text { alveolar fluid and lung. } \\
\text { - } \text { pcDNA3-CpG group prevented hyperres- } \\
\text { ponsiveness of the via area to } T \text {. canis } \\
\text { infection. } \\
\text { - Important level of anti- } T \text { canis IgG, where } \\
\text { subclass IgG1 was the most important in } \\
\text { both groups. }\end{array}$ & $\begin{array}{l}\text { (Malheiro } \\
\text { et al., 2008) }\end{array}$ \\
\hline Balb/c mice & $\begin{array}{l}\text { T. canis hatching liquid (first } \\
\text { dose } 0.3 \mathrm{ml} \text { of } 1000 \text { egg } \\
\text { supernatant, } 21 \text { days then } 0.15 \\
\mathrm{ml} \text { of } 500 \text { egg supernatant) }\end{array}$ & $\begin{array}{l}\text { Reduction of number of } T \text {. cati larvae } \\
\text { obtained post-mortem (liver, lung, muscle) } \\
\text { compared with the control group: } 65.34 \% \\
\text { SC, } 56.25 \% \text { IM and } 68.18 \% \text { IP. } \\
\text { Reduction of the number of } T \text {. leonina } \\
\text { larvae obtained after death (liver, lung, } \\
\text { muscle) compared to the control group: } \\
67.34 \% \text { SC, } 66.83 \% \text { IM and } 61.22 \% \text { IP. }\end{array}$ & $\begin{array}{l}\text { (Hosin and Al- } \\
\text { Kubaysi, 2008) }\end{array}$ \\
\hline Swiss mice & $\begin{array}{l}\text { Saccharomyces boulardii } \\
\text { (probiotic) } 107 \text { CFU/g of food }\end{array}$ & $\begin{array}{l}36.7 \% \text { reduction in the recovery } \\
\text { of post-mortem larvae of } T \text {. canis in } \\
\text { several tissues }(p=0.0002) \text {. }\end{array}$ & $\begin{array}{l}\text { (de Avila } \\
\text { et al., 2012) }\end{array}$ \\
\hline Albino rats & $\begin{array}{l}\text { T. vitolorum eggs exposed } \\
\text { to } 600 \mathrm{~Gy} \text { and } 800 \mathrm{~Gy} y \\
\text { radiations ( } 1500 \text { eggs } \mathrm{PO})\end{array}$ & $\begin{array}{l}\text { The histopathological changes caused } \\
\text { by infection with } T \text {. vitulorum decreased } \\
\text { by increasing the dose of irradiation of } \\
\text { the infected stage, radiation exposure } \\
\text { attenuated the larval migration from } \\
\text { the gastrointestinal tract to liver. }\end{array}$ & $\begin{array}{l}\text { (El-Kabany, } \\
\text { 2013) }\end{array}$ \\
\hline Albino rats & $\begin{array}{l}800 \text { Gy and } 600 \text { Gy irradiated } \\
\text { T. canis eggs ( } 2500 \text { eggs PO) }\end{array}$ & $\begin{array}{l}\text { Glutathione peroxidase activity in kidney } \\
\text { tissues }(\mathrm{U} / \mathrm{gHb}): 25.78 \pm 0.4 \text { control } \\
\text { group; } 26.3 \pm 0.1600 \text { Gy group and } \\
29.14 \pm 0.2800 \text { Gy group ( } \mathrm{p}<0.05) \text {. } \\
\text { Superoxide dismutase activities in } \\
\text { kidney tissues }(\mathrm{U} / \mathrm{gHb}): 3.82 \pm 0.1 \text { control } \\
\text { group; } 5.13 \pm 0.1600 \mathrm{~Gy} \text { group and } \\
5.40 \pm 0.2800 \mathrm{~Gy} \text { group ( } \mathrm{p}<0.05) . \\
800 \mathrm{~Gy} \text { group ameliorated the } \\
\text { biochemical, haematological and } \\
\text { histopathological of renal toxocariasis. }\end{array}$ & $\begin{array}{l}\text { (Moawad } \\
\text { et al., 2015) }\end{array}$ \\
\hline
\end{tabular}




\begin{tabular}{|c|c|c|c|}
\hline $\begin{array}{l}\text { Experimental } \\
\text { model }\end{array}$ & Experimental vaccine/adjuvant & Result & Ref. \\
\hline Albino rats & $\begin{array}{l}\text { - Gamma radiation-attenuated em- } \\
\text { bryonated egg T. canis (800 eggs } \\
\text { PO) } \\
\text { - Essential oil of the Thymus } \\
\text { vulgaris - Thyme }(42.5 \mathrm{mg} / \mathrm{kg} \text { PO) }\end{array}$ & $\begin{array}{l}\text { Toxocara canis larvae counts in brain } \\
\text { tissue, } \% \text { of recovered larvae: } 38.4 \% \\
\text { control group; } 8.4 \% \text { Gamma eggs group } \\
\text { and } 14 \% \text { Thyme group }(\mathrm{p}<0.05) \text {. } \\
\text { Nitric oxide levels }(\mu \mathrm{mol} / \mathrm{L}) \text { in rats } \\
\text { brain cells: } 37.9 \pm 0.8 \mathrm{control} \text { group; } \\
23.3 \pm 0.2 \text { Gamma eggs group and } \\
26.5 \pm 0.2 \text { Thyme group ( } \mathrm{p}<0.05) \text {. } \\
\text { Gamma eggs and Thyme group improvement } \\
\text { in the histopathological lesions and } \\
\text { DNA fragmentations as well as damage } \\
\text { in brain tissues Vs control group. }\end{array}$ & $\begin{array}{l}\text { (Amin } \\
\text { et al., 2016) }\end{array}$ \\
\hline Mixed-breed dog & $\begin{array}{l}\text { TES }(36 \mu \mathrm{g}) \text { T. canis }+ \\
\mathrm{FCA}+\mathrm{Al}(\mathrm{OH})_{3} \mathrm{IM}\end{array}$ & $\begin{array}{l}\text { Considerable decrease in the } \\
\text { counting eggs per gram of feces. }\end{array}$ & $\begin{array}{l}\text { (Martín } \\
\text { et al., 2016) }\end{array}$ \\
\hline Albino rats & $\begin{aligned} & \text { - } \text { Toxocara eggs exposed } \\
& \text { - } \text { to 800Gy y radiations (PO) } \\
& \text { - Essential oil of Thymus vulgaris } \\
& \\
& \text { (42.5 mg/kg BW PO). }\end{aligned}$ & $\begin{array}{l}\text { Vaccination with eggs attenuated by } \\
\text { radiation and T. vulgaris oil significantly } \\
\text { reduced, in comparison with the } \\
\text { control group, the histopathological, } \\
\text { histochemical and immunohistochemical } \\
\text { changes in testicular parenchyma. }\end{array}$ & $\begin{array}{l}\text { (Hafez et } \\
\text { al., 2019) }\end{array}$ \\
\hline
\end{tabular}

SC: subcutaneous, PO: oral, IP: intraperitoneal, IM: intramuscular, BW: body weight

analysis of TES proteins using liquid chromatographytandem mass spectrometry, identifying 19 proteins from the parasite's genome. More detailed studies in proteomics developed by our research team (da Silva et al., 2018) have identified 582 proteins from larval extract and 64 proteins in TES. In this study we identified proteins that include immunomodulatory molecules involved in the evasion mechanisms and those that may be involved in pathogenicity. Some of these proteins have potential for the development of immunotherapy and immunodiagnosis. Based on these studies a series of proteins of immunological interest have been identified as vaccines candidates using reverse vaccinology. Some of these proteins include: A) TES-32 - a secreted protein that shows similarity with C-type lectins present in mammalian immune cells in the pathogen response process, molecular weight $32 \mathrm{KDa}$ and composed of 219 amino acids (aa) (Maizels et al., 2000), B) TES-26 (TC-PEB-1) - Phosphatidylethanolamine-bound protein, composed of 262 aa and a molecular weight of 26 KDa (Gems et al., 1995), C) TES-120 (Tc-MUC-3) - mucin-3 composed of 269 aa and a molecular weight of 45 KDa (Loukas et al., 2000a) and D) TES-70 (Tc-CTL-4) - C-type Lectin-4 composed of 288 aa and a molecular weight $70 \mathrm{KDa}$, identified as an important canine cell surface ligation protein (Loukas et al., 2000b). TES and somatic proteins from the worms' surfaces are potential vaccine candidates because of their ability to generate a specific antibody response. However, their potency and efficiency of immune system stimulation is controversial (Soltys et al., 1996; Munn, 1997; Dvorožňáková et al., 2000; Dvorožňáko et al., 2002).

Vaccines are preparations used to stimulate humoral and cellular immunity against a specific pathogen, and are prepared using a harmless form such as the attenuated organisms or their recombinant proteins (Hewitson and Maizels, 2014; Han, 2015). To achieve its maximum immunogenic potential, it is strictly necessary to use adjuvants (Chan and Gack, 2016). Adjuvants exert their function by increasing the efficacy of antigens through the stimulation of the innate immune system, directly by stimulating DCs, macrophages and neutrophils, which lead to the activation of the adaptive immune system (Bonam et al., 2017). Nowadays, the use of adjuvants in vaccination seeks to direct the response of the adaptive immune system to the inoculated antigen (Reed et al., 2016), an action called "adjuvant effect". This effect is the administration of an antigen with a specific microbial, among other compounds with biological activity, to enhance a specific immune response to the antigen. The microbial components of the adjuvants activate antigen presenting cells (APC) to produce pro-inflammatory cytokines and to upregulate the essential molecules for antigen pre- 
sentation. An example of these molecules is the major histocompatibility complex (MHC) class II and B7-1/2 (CD80/CD86, co-stimulatory signaling of B lymphocytes and mononuclear phagocytes). This adjuvant effect allows a more effective antigen presentation, resulting in activation and clonal expansion of $\mathrm{T}$ cells (O'Hagan and Valiante, 2003).

There are several adjuvants that can provide greater potency and efficacy of $T$. canis TES and surface somatic antigens, such as imidazoquinolines ( $\mathrm{Th}_{1}$ immune response adjuvants) which activate TLR7 and TLR8 (single stranded RNA receptors). After imidazoquinolines bind to these TLRs, transcription factors initiate transcription of multiple pro-inflammatory cytokines such as IL-17, which plays an important role in cellular immunity, particularly in infection-responsive immune response (Ma et al., 2010). Thus, after stimulation with this adjuvant there is a general increase in IL-17 producing thymocytes, which are relevant cells in the response to infectious pathogens and tumors (Cho and Celis, 2009). Allthough a classic adjuvant is aluminum hydroxide ( $\mathrm{Th}_{2}$ immune response adjuvant), the mechanisms of its immunomodulation are still not completely elucidated. HogenEsch (2002) summarized the possible activities of aluminum salts as modulators of the immune responses by stimulating directly and indirectly dendritic cells and complement activation. Other studies have found induction of chemokine secretion (Ulanova et al., 2001). It has also been shown that aluminum salts develop inflammasome responses (e.g. NALP3) and IL-1 $\beta$ secretion (Eisenbarth et al., 2008). Recently, there are new adjuvants capable of stimulating a balanced $T h_{1} / T_{2}$ responses, which is beneficial for immunoprophylaxis of helminthiasis (Diemert et al., 2018). One of these is the purified fraction of saponins (triterpenoid glucoside) extracted from the bark of the Quillaja saponaria, a Molina tree. In addition to its use as a surfactant, it is also used in a pseudo-ternary system with cholesterol and phospholipid to form colloidal structures known as ISCOM (immunostimulating complexes) (Kensil, 1996). These saponins generate a strong response to $\mathrm{T}$ cell dependent and non-dependent antigens (Petrovsky and Aguilar, 2004). They also induce cytotoxic $\mathrm{CD}^{+} \mathrm{T}$ cell proliferation and response (Newman et al., 1992) and enhance the response to mucosal antigens (Singh and O'Hagan, 2003). Another example of these new adjuvants is the AS01, which is composed of liposomes containing two immunostimulants: 3-O-deacyl-4'-monophosphoryl lipid A (MPL) and QS-21. MPL is a non-toxic LPS-derived compound from Salmonella minnesota and QS-21 is a saponin extracted from Q. saponaria (Didierlaurent et al., 2016). They act as agonists and synergistically bind to TLR4 inducing resident $\mathrm{NK}$ cells and $\mathrm{CD} 8^{+} \mathrm{T}$ cells to release IFN- $\gamma$ into the regional lymph node, activate the macrophages and IL-12 and IL-18 secretion, hours after AS01 application (Marty-Roix et al., 2016 ).

Other adjuvants that may provide greater potency and efficacy of the $T$. canis TES and surface somatic antigens are the synthetic TLR1/TLR2 (Th1 immune response adjuvants) agonists such as triacylated lipopeptides which include Pam3CSK4, a molecule that mimics the acylated amino terminus of bacterial lipopeptides, and has the ability to bind to different receptors. TLR activating pro-inflammatory transcriptional factors such as NF- $\mathrm{kB}$ and modulating both cellular and humoral immune responses (Steinhagen et al., 2011). The immunogenic effect of Pam3CSK4 is underpinned by its ability to negatively regulates IL-13 and IL-10 responses (Pratti et al., 2016) and to lead $\mathrm{Th}_{1}$ immune response-based production of IFN- $\gamma$ and TNF- $\alpha$ (Martínez-Orellana et al., 2017). In addition, Liu et al., (2013) showed that intravenous administrations of TLR-1/-2 ligands were able to activate the MyD88 signaling pathway and promote $\mathrm{T}$ cell differentiation through IL-12 secretion.

\section{Final consideration}

Finally, it is important to clarify the emerging role of domestic cats in toxocariasis, recent studies have shown that domestic cats are a significant source of $T$. cati eggs for the environment, having a possible preponderant role within this zoonosis (Lucio-Forster et al, 2016). From the epidemiological perspective, conventional diagnostic tests (serodiagnosis using anti-lgGTES, parasitological tests in feces) do not differentiate infectious agents that cause toxocariasis in animals or people (de Savigny et al., 1979; Zhu et al., 1998, Alcântara -Neves et al., 2008) generating a dismissal of $T$. cati as a causative agent of human and animal clinical toxocariasis (Fisher, 2003). Although there are specific diagnostic, methods such as PCR using the second internal transcribed spacer (ITS-2) of the ribosomal DNA of $T$. canis, T. cati and Toxascaris leonina (Jacobs et al., 1997) they are used only in research. Other serodiagnostic tests such as ELISA, excretory-secretory antigen (ES Ag) from T. cati larvae for the diagnosis of human toxocariasis caused by T. cati (Petithory and Beddock, 1997) and Western blot using T. canis and T. cati ES Ag (Poulsen et al., 2015) have generated controversial results (i.e. cross reaction). It is possible that the cross reaction between $T$. canis and $T$. cati in seodiagnostics techniques is due to a) their somatic protein and TES homologues (Kennedy et al., 1987; Zahabiun et al., 2015); b) the low intraspecific variation between the- 
se helminths of different geographical regions (Zhu et al., 2000; Fogt-Wyrwas et al., 2013) and c) cross protection between T. cati and T. canis (Hosin and Al-Kubaysi, 2008). These actions could allow a single immunotherapeutic development to be able to control the two most important parasitic agents of this zoonosis in the world.

\section{Conclusion}

Toxocariasis is a disease that must be controlled in domestic and stray dogs and cats. This disease has a direct relationship with humans and has a potential zoonotic connotation. Among the control strategies, vaccination plays a major role by altering the parasitic cycle (i.e. vertical transmission: transplacental and transmammary infection) or significantly reducing the viability of eggs and their environmental concentration, consequently reducing the possibility of human infection. Given all the important advances in the molecular characterization of $T$. canis (transcriptomics, proteomics and genomics), and the identification of vaccine candidate proteins, reverse vaccinology is a potential strategy for the development of immunoprophylactic compounds. These studies would allow the generation of new vaccine antigens that can be enhanced by the use of the latest generation of adjuvants, thus creating one of the fundamental pillars in the integrated control of one of the most important neglected zoonotic parasitic disease that affects the poor human populations in the world.

\section{Competing interests}

The authors declare that they have no known competing financial interests or personal relationships that could have appeared to influence the work reported in this paper.

\section{Acknowledgments}

This study was supported financially by RENORBIO/ $\mathrm{CNPq}$ and Alergy and Acarology Laboratory from Federal University of Bahia. To professor Eric Roberto Guimarães Rocha Aguiar of the Institute of Health Sciences, for his contributions in the improvement of figures 2 and 3 of this article.

\section{References}

Abo-Shehada MN, Al-Zubaidy BA, Herbert IV. Acquired immunity to Toxocara canis infection in mice. Vet. Parasitol. 1991;38:28998.

Agudelo C, Villareal E, Cáceres E, López C, Eljach J, Ramírez N, Hernández C, Corredor A. Human and dogs Toxocara canis infec- tion in a poor neighborhood in Bogotá. Mem. Inst. Oswaldo Cruz. 1990;85:75-78.

Alcântara-Neves NM, Bavia E, Silvão RM, Carvalho E. Environmental contamination by Toxocara sp eggs in public areas of Salvador, Bahia state, Brazil. Rev. Soc. Bras. Med. Trop. 1989;22:187-190.

Alcântara-Neves NM, dos Santos AB, Mendonça LR, Figueiredo CA, Pontes-de-Carvalho L. An improved method to obtain antigen-excreting Toxocara canis larvae. Exp. Parasitol. 2008;119:349-351.

Alcântara-Neves NM, de S G Britto G, Veiga RV, Figueiredo CA, Fiaccone RL, et al. Effects of helminth co-infections on atopy, asthma and cytokine production in children living in a poor urban area in Latin America. BMC Res. Notes. 2014;7:817.

Amerasinghe PH, Rajapakse RP, Lloyd T, Feernando ST. Antigeninduced protection against infection with Toxocara vitulorum larvae in mice. Parasitol. Res. 1992;78:643-647.

Amin MM, El-Kabany $\mathrm{H}$. Evaluation of protective and treatment of Thyme (Thymus vulgaris) oil on Toxocara vitulorum infected rats. J. Rad. Res. Appl. Sci. 2013;1:209.

Aydenizöz-Ozkayhan M, Yağcl BB, Erat S. The investigation of Toxocara canis eggs in coats of different dog breeds as a potential transmission route in human toxocariasis. Vet. Parasitol. 2008;152:94-100.

Barriga OO. A critical look at the importance, prevalence and control of toxocariasis and the possibilities of immunological control. Vet. Parasitol. 1988;29:195-234.

Barriga OO. Rational control of canine toxocariasis by the veterinary practioner. J. Am. Vet. Med. Assoc. 1991;98:216-221.

Batchelor DJ, Tzannes S, Graham PA, Wastling JM, Pinchbeck GL, German AJ. Detection of endoparasites with zoonotic potential in dogs with gastrointestinal disease in the UK. Transbound Emerg. Dis. 2008;55:99-104.

Beaver PC. Toxocariasis (visceral larva migrans) in relation to tropical eosinophilia. Bull. Soc. Path. Exot. 1962;55:555-576.

Berrett A. Toxocara Seroprevalence and Associated Risk Factors in the United States. Am. J. Trop. Med. Hyg. 2017;97:1846-1850.

Bonam SR, Partidos CD, Halmuthur SKM, Muller S. An overview of novel adjuvants designed for improving vaccine efficacy. Trends Pharmacol. Sci. 2017;38:771-793.

Bowman DD. Heartworms, macrocyclic lactones, and the specter of resistance to prevention in the United States. Parasite. Vector. 2012;5:13.

Bowman DD. 2014. Helminths. Georgis' Parasitology for Veterinarians E-Book, 10th ed. Saunders, St. Louis, MO, Pp. 122-240.

Buitrago B, Gast-Galvis A.Visceral larva migrans syndrome (Larval Granulomatosis) in Colombia. Rev. Soc. Colomb. Pediatr. Pueric. 1965;6:89-95.

CAPC, 2016. Companion Animal Parasite Council, Recommendations on Parasite Control-Hookworms. https://www.capcvet. org/capc-recommendations/hookworms/) (Search November 10, 2019) 
CDC, 2014. Centers for Disease Control and Prevention Neglected Parasitic Infections in the United States. http://www.cdc.gov/ parasites/npi/index.html (Search October 02, 2017).

Chan YK, Gack MU. Viral evasion of intracellular DNA and RNA sensing. Nat. Rev. Microbiol. 2016;14:360-373.

Chen J, Liu Q, Liu GH, Zheng WB, Hong SJ, Sugiyama H, Zhu XQ, Elsheikha HM. Toxocariasis: a silent threat with a progressive public health impact. Infect. Dis. Poverty. 2018;7:59.

Cho HI, Celis E. Optimized Peptide Vaccines Eliciting Extensive CD8 T-Cell Responses with Therapeutic Antitumor Effects. Cancer Res. 2009;69:9012-9019.

Claerebout E. Giardia and other intestinal parasites in different dog populations in Northern Belgium. Vet. Parasitol. 2009;161:41-46.

Concepcion JE, Barriga OO. Transfer of infection-induced immune protection to Toxocara canis in a mouse model. Vet. Immunol. Immunopathol. 1985;9:371-382.

Cong W, Zhang XX, Zhou N, Yu CZ, Chen J, Wang XY, Li B, Quian AD, Zhu XQ. Toxocara seroprevalence among clinically healthy individuals, pregnant women and psychiatric patients and associated risk factors in Shandong Province, Eastern China. PLoS Negl. Trop. Dis. 2014;8:e3082.

Cooper PJ, Chico M, Sandoval C, Espinel I, Guevara A, Levine MM, Griffin GE, Nutman TB. Human infection with Ascaris lumbricoides is associated with suppression of the interleukin-2 response to recombinant cholera toxin $\mathrm{B}$ subunit following vaccination with the live oral cholera vaccine CVD 103-HgR. Infect. Immun. 2001;69:1574-1580.

da Silva MB, Urrego AJR, Oviedo Y, Cooper PJ, Pacheco LGC, Pinheiro CS, Ferreira F, Briza P, Alcantara-Neves NM. The somatic proteins of Toxocara canis larvae and excretory-secretory products revealed by proteomics. Vet. Parasitol. 2018;259:25-34.

Dai RS, Li ZY, Li F, Liu DX, Liu W, Liu GH, et al. Severe infection of adult dogs with helminths in Hunan Province, China poses significant public health concerns. Vet. Parasitol. 2009;160:348-350.

de Avila LFDC, Conceição FR, de Lima Telmo P, Dutra GF, de los Santos DG, Martins LHR, Berne NE, da Silva PE, Scaini CJ. Saccharomyces boulardii reduces infection intensity of mice with toxocariasis. Vet. Parasitol. 2012;187:337-340.

de Savigny DH, Voller A, Woodruff AW. Toxocariasis: serological diagnosis by enzyme-linked immunosorbent assay. J. Clin. Pathol. 1979;32:284-288.

Del Tordello E, Rappuoli R, Delany I. 2017. Reverse Vaccinology: Exploiting Genomes for Vaccine Design. In: Modjarrad, K., Koff, WC. (Eds). Human Vaccines Emerging Technologies in Design and Development. Ed. Academic Press. London, UK, Pp. 65-86.

Despommier D. Toxocariasis: Clinical Aspects, Epidemiology, Medical Ecology, and Molecular Aspects. Clin. Microbiol. Rev. 2003; 16:265-272.

Didierlaurent AM, Laupèze B, Di Pasquale A, Hergli N, Collignon C, Garçon N. Adjuvant system AS01: helping to overcome the challenges of modern vaccines. Expert Rev. Vaccines. 2016;16:55-63.
Diemert DJ, Bottazzi ME, Plieskatt J, Hotez PJ, Bethony JM.Lessons along the critical path: developing vaccines against human helminths. Trends Parasitol. 2018;34:747-758.

Doğan EC, Dinleyici EÇ, Bor Ö, Töz SÖ, Özbel Y. Seroepidemiological survey for Toxocara canis infection in the northwestern part of Turkey. Turkiye Parazitol. Derg. 2007;31:288-291.

Du L, Wei H, Li L, Shan H, Yu Y, Wang Y, Zhang G. Regulation of recombinant Trichinella spiralis $53 \mathrm{kDa}$ protein (rTsP53) on alternatively activated macrophages via STAT6 but not IL-4R $\alpha$ in vitro. Cell. Immunol. 2014;288:1-7.

Dvorožňáková E. Immunomodulative effect of muramyldipeptide in mice with larval toxocarosis. Parasitol. Res. 1999;85:10341040 .

Dvorožňáková E, Borošková Z, Dubinský $\mathrm{P}$, Tomašovičová $\mathrm{O}, \mathrm{Ma}-$ chnicka B. Toxocara cants in mice: immune responses after infection and immunization. Helminthologia. 2000;37:199-204.

Dvorožňáková $\mathrm{E}$, Borošková $\mathrm{Z}$, Tomašovičová $\mathrm{O}$. Immune responses in mice immunized with Toxocara canis antigens. Helminthologia. 2002;39:59-66.

Eisenbarth SC, Colegio OR, O'Connor W, Sutterwala FS, Flavell RA. Crucial role for the Nalp3 inflammasome in the immunostimulatory properties of aluminium adjuvants. Nature. 2008;453:1122-1126.

El-Kabany H. Biochemical and histopathological studies on liver of rats infected with non irradiated and/or Irradiated Toxocara vitulorum eggs. J. Radiat. Res. Appl. Sc. 2013;6:137-154.

Fallah A, Azimi A, Taherkhani H. Seroprevalence of toxocariasis in children aged 1-9 years in western Islamic Republic of Iran, 2003. East Mediterr. Health J. 2007;13:1073-1077.

Fisher M.Toxocara cati: an underestimated zoonotic agent. Trends Parasitol. 2003;19: 167-170.

Finsterer J, Auer H. Neurotoxocarosis. ver. Inst. Med. Trop. são. Paulo. 2007;49:279-287.

Fogt-Wyrwas R, Mizgajska-Wiktor H, Pacoń J, Jarosz W.Intraspecific variation between the ITS sequences of Toxocara canis, Toxocara cati and Toxascaris leonina from different host species in south-western Poland. J. Helminthol. 2013;87:432-442.

Gasser R, Zhu XQ, Jacobs DE, Hu M, Chilton NB. 2006. Molecular genetic characterization of members of the genus Toxocara taxonomic, population genetic and epidemiological considerations. In: Holland, C.V., Smith, H.V. (1st ed). Toxocara The Enigmatic Parasite. CABI Publishing. United Kingdom, Wallingford, Pp. 18-31.

Gasser RB. A perfect time to harness advanced molecular technologies to explore the fundamental biology of Toxocara species. Vet. Parasitol. 2013;193:353-364.

Gauci Ch, Vural G, Öncel T, Varcasia A, Damian V, Kyngdon CT, Craig PS, Anderson GA, Lightowlers MW. Vaccination with recombinant oncosphere antigens reduces the susceptibility of sheep to infection with Taenia multiceps. Int J. Parasitol. 2008;38:1041-1050. 
Gems DH, Ferguson CJ, Robertson BD, Nieves R, Page AP, Blaxter ML, Maizels RM. An abundant, trans-spliced mRNA from Toxocara canis infective larvae encodes a $26-\mathrm{kDa}$ protein with homology to phosphatidylethanolamine-binding proteins. J. Biol. Chem. 1995;270:18517-18522.

Giraldo MI, García NL, Castaño JC. Prevalence of intestinal helminths in dogs from Quindio province. Biomédica. 2005;25:346-352.

González-Hernández A, Van Coppernolle S, Borloo J, Van Meulder F, Paerewijck O, Peelaers I, Leclercq G, Claerebout E, Geldhof P.Host protective ASP-based vaccine against the parasitic nematode Ostertagia ostertagi triggers NK cell activation and mixed IgG1-IgG2 response. Sci. Rep. 2016;6:29496.

Gordon S. Pattern recognition receptors: doubling up for the innate immune response. Cell. 2002;111:927-930.

Grencis RK, Entwistle GM.Production of an interferon-gamma homologue by an intestinal nematode: functionally significant or interesting artefact? Parasitology. 1997;115:S101-106.

Habluetzel A, Traldi G, Ruggieri S, Attili AR, Scuppa P, Marchetti R, Menghini G, Esposito F. An estimation of Toxocara canis prevalence in dogs, environmental egg contamination and risk of human infection in the Marche region of Italy. Vet. Parasitol. 2003; 113:243-252.

Hafez EN, Hafez MN, Amin MM. Effect of vaccination with irradiated Toxocara canis larvae or thyme oil treatment on testicular histochemical and immunohistochemical changes of rats. Trop. Biomed. 2019;36:430-442.

Han S. Clinical vaccine development. Clin. Exp. Vaccine. Res. 2015;4:46-53.

Haridy FM, Hassan AA, Hafez AO, El-Sherbini GT, Morsy TA. External and intestinal parasites of pet dogs with reference to zoonotic toxocariasis. J. Egypt. Soc. Parasitol. 2009;39:321-326.

Hayashi E. The high prevalence of asymptomatic Toxocara infection among schoolchildren in Manado, Indonesia, Southeast Asian. J. Trop. Med. Public Health. 2005;36:1399-1406.

Helmby H, Grencis RK. Essential role for TLR4 and MyD88 in the development of chronic intestinal nematode infection. Eur. J. Immunol. 2003;33:2974-2979.

Hewitson JP, Maizels RM. Vaccination against helminth parasite infections. Expert Rev. Vaccines. 2014;13:473-487.

Hewitson JP, Grainger JR, Maizels RM.Helminth immunoregulation: the role of parasite secreted proteins in modulating host immunity. Mol. Biochem. Parasitol. 2009;167:1-11.

HogenEsch $\mathrm{H}$. Mechanisms of stimulation of the immune response by aluminum adjuvants. Vaccine. 2002;20:S34-S39.

Holland CV. Knowledge gaps in the epidemiology of Toxocara: the enigma remains. Parasitology. 2017;144:81-94.

Hosin AB, Al- Kubaysi SMA. Efficiency of Immunization with the Hatching Fluid of Toxocara canis and Toxascaris leonina eggs against infection with Toxascaris leonina and Toxocara cati larvae. Al- Anbar J. Vet. Sci. 2008;1:1-9.
Hotez PJ, Wilkins PP. Toxocariasis: America's most common neglected infection of poverty and a helminthiasis of global importance? PLoS Negl. Trop. Dis. 2009;3: e400.

Izzat NN, Olson JJ. Resistance of mice to Toxocara canis: effect of prechallenge infections and injection of worm extracts. Can. J. Zool. 1970;48:1063-1066.

Jacobs DE, Zhu X, Gasser RB, Chilton NB. PCR-based methods for identification of potentially zoonotic ascaridoid parasites of the dog, fox and cat. Acta Trop. 1997;68:191-200.

Jarosz W, Mizgajska-Wiktor H, Kirwan P, Konarski J, Rychlicki W, Wawrzyniak G. Developmental age, physical fitness and Toxocara seroprevalence amongst lower-secondary students living in rural areas contaminated with Toxocara eggs. Parasitology. 2010;137:53-63.

Jones L, Kruszon-Moran D, Won K, Wilson M, Schantz PM. Toxoplasma gondii and Toxocara spp. co-infection. Am. J. Trop. Med. Hyg. 2008;78:35-39.

Kennedy MW, Maizels RM, Meghii M, Young L, Qureshi F, Smith HV.Species-specific and common epitopes on the secreted and surface antigens of Toxocara cati and Toxocara canis infective larvae. Parasite Immunol. 1987;9:407-420.

Kamiya M, Ooi HK, Nomura T. The effect of radiation on the viability and migratory ability of second-stage larvae of Toxocara canis in mice. Vet. Parasitol. 1987;24:87-92.

Kensil CR. Saponins as vaccine adjuvants. Crit. Rev. Ther. Drug Carrier Syst. 1996;13:1-55

Köhler P.The biochemical basis of anthelmintic action and resistance. Int. J. Parasitol. 2001;31:336-345.

Kollipara R, Peranteau AJ, Nawas ZY, Tong Y, Woc-Colburn L, Yan AC, Lupi O, Tyring SK. Emerging infectious diseases with cutaneous manifestations: fungal, helminthic, protozoan and ectoparasitic infections. J. Am. Acad. Dermatol. 2016;75:19-30.

Kopp SR, Coleman GT, Traub RJ, McCarthy JS, Kotze AC. Acetylcholine receptor subunit genes from Ancylostoma caninum: altered transcription patterns associated with pyrantel resistance. Int. J. Parasitol. 2009;39:435-441.

Layland LE, Straubinger K, Ritter M, Loffredo-Verde E, Garn H, Sparwasser T, da Costa CP. Schistosoma mansoni-mediated suppression of allergic airway inflammation requires patency and Foxp3+ Treg cells. PLoS Negl. Trop. Dis. 2013;7:e2379.

Le TH, Anh NTL, Nguyen KT, Nguyen NTB, Gasser RB. Toxocara malaysiensis infection in domestic cats in Vietnam - An emerging zoonotic issue? Infect. Genet. Evol. 2016;37:94-98.

Lee RM, Moore LB, Bottazzi ME, Hotez PJ. Toxocariasis in North America: a systematic review. PLoS Negl. Trop. Dis. 2014;8:e3116.

Li K, Lan Y, Luo H, Zhang H, Liu D, Zhang L, Li J.Prevalence, associated risk factors, and phylogenetic analysis of Toxocara vitulorum infection in yaks on the Qinghai Tibetan plateau, China. Korean J Parasitol. 2016;54:645-652.

Liu J, Jiang M, Ma Z, Dietze KK, Zelinskyy G, Yang D, Dittmer U, Schlaak JF, Roggendorf M, Lu M.TLR1/2 ligand stimulated 
mouse liver endothelial cells secrete IL-12 and trigger CD8 + T cell immunity in vitro. J. Immunol. 2013;191:6178-6190.

Loukas AC, Hintz M, Linder D, Mullin NP, Parkinson J, Tetteh KK, Maizels RM.A family of secreted mucins from the parasitic nematode Toxocara canis bears diverse mucin domains but shares similar flanking six-cysteine repeat motifs. J. Biol. Chem. 2000a; 275:39600-7.

Loukas AC, Doedens A, Hintz M, Maizels RM.Identification of a new C-type lectin, TES-70, secreted by infective larvae of Toxocara canis, which binds to host ligands. Parasitology 2000a. 2000b; 121:545-554

Lucio-Forster A, Mizhquiri JF, Mohammed HO, Kornreich BG, Bowman DD.Comparison of the prevalence of Toxocara egg shedding by pet cats and dogs in the U.S.A., 2011-2014. Vet. Parasitol. Reg. Stud. Reports. 2016;5:1-13.

Macpherson $\mathrm{CN}$. The epidemiology and public health importance of toxocariasis: a zoonosis of global importance. Int. J. Parasitol. 2013;43:999-1008.

Ma F, Zhang J, Zhang J, Zhang C. The TLR7 agonists imiquimod and gardiquimod improve DC-based immunotherapy for melanoma in mice. Cell Mol. Immunol. 2010;7:381-388.

Ma G, Holland CV, Wang T, Hofmann A, Fan C, Maizels RM, Hotez PJ, Gasser RB. Human toxocariasis. Lancet Infect. Dis. 2018a;18:e14-e24.

Ma G, Wang T, Korhonen PK, Nie S, Reid GE, Stroehlein AJ, Koehler AV, Chang BCH, Hofmann A, Young ND, Gasser RB. Comparative bioinformatic analysis suggests that specific dauer-like signalling pathway components regulate Toxocara canis development and migration in the mammalian host. Parasite. Vector. 2019;12:32.

Ma GX, Zhou RQ, Hu L, Luo YL, Luo YF, Zhu HH. Molecular characterization and transcriptional analysis of the female-enriched chondroitin proteoglycan 2 of Toxocara canis. J. Helminthol. 2018b:92:154-160.

Magnaval JF, Glickman LT, Dorchies P, Morassin B. Highlights of human toxocariasis. Korean J. Parasitol. 2001;39:1-11.

Malheiro A, Aníbal FF, Martins-Filho OA, Teixeira-Carvalho A, Perini A, Martins MA, Medeiros Al, Turato WM, Acencio MPM, Brandão IT, Nomizo A, Silva CL, Facciolia LH. pcDNA-IL-12 vaccination blocks eosinophilic inflammation but not airway hyperresponsiveness following murine Toxocara canis infection. Vaccine. 2008;26:305-315.

Maizels RM, Tetteh KK, Loukas A. Toxocara canis: genes expressed by the arrested infective larval stage of a parasitic nematode. Int. J. Parasitol. 2000;30:495-450.

Maizels RM. Toxocara canis: Molecular basis of immune recognition and evasion. Vet. Parasitol. 2013:193:365-374.

Maizels RM, Loukas A. 2001. The surface and secreted antigens of Toxocara canis: genes, protein structure and function. In: Kennedy MW, Harnett W. (Eds.), Parasitic Nematodes: Molecular Biology, Biochemistry and Immunology. Wallingford, UK, pp. 229-247.

Maizels RM. 2006. Molecular biology and immunology of Toxocara canis. In: Holland CV, Smith HV. (1st ed) Toxocara The Enig- matic Parasite. CABI Publishing. United Kingdom, Wallingford, pp. 3-17.

Maizels RM, Mcsorley HJ. Regulation of the host immune system by helminth parasites. J. Allergy Clin. Immunol. 2016;138:666-675.

Mardis ER. The impact of next-generation sequencing technologyon genetics. Trends Genet. 2008;24:133-141.

Marmor M, Glickman L, Shofer F, Faich LA, Rosenberg CARL, Cornblatt BAR, Friedman S. Toxocara canis infection of children: epidemiologic and neuropsychologic findings. Am. J. Public Health. 1987;77:554-559.

Martín UO, Cordani FM, Demonte MA, Pepino S, García LD. Hacia un control inmunológico de la toxocariasis: inmunoprotección en canes con antígenos de Toxocara canis. Rev. Vet. 2016;27:28-31.

Martínez-Orellana $\mathrm{P}$, Quirola-Amores $\mathrm{P}$, Montserrat-Sangrà $\mathrm{S}$, Ordeix L, Llull J, Álvarez-Fernández A, Solano-Gallego L. The inflammatory cytokine effect of Pam3CSK4 TLR2 agonist alone or in combination with Leishmania infantum antigen on ex vivo whole blood from sick and resistant dogs. Parasit. Vectors. 2017; 10:123.

Marty-Roix R, Vladimer GI, Pouliot K, Weng D, Buglione-Corbett R, West K, MacMicking JD, Chee JD, Wang S, Lu S, Lien E. Identification of QS-21 as an Inflammasome-activating molecular component of saponin adjuvants. J. Biol. Chem. 2016;291:1123-1136.

Marques JP, Guimarães C, Boas AV, Carnaúba PU, de Moraes J.Contamination of public parks and squares from Guarulhos (São Paulo State, Brazil) by Toxocara spp. and Ancylostoma spp. Rev. Inst. Med. trop. S. Paulo. 2012;54:267-271.

Meghji M, Maizels RM. Biochemical properties of larval excretorysecretory glycoproteins of the parasitic nematode Toxocara canis. Mol. Biochem. Parasitol. 1986;18:155-170.

Mendonça LR, Veiga RV, Dattoli VCC, Figueiredo CA, Fiaccone R, Santos J, Cruz AA, Rodrigues LC, Cooper PJ, Pontes-de-Carvalho LC, Barreto ML, Alcantara-Neves NM.Toxocara seropositivity, atopy and wheezing in children living in poor neighbourhoods in urban Latin American. PLoS Negl Trop Dis. 2012;6:e1886.

Merigueti YF, Santarém VA, Ramires LM, da Silveira BA, da Costa BLV, Nuci AL, de Paula ETM. Protective and risk factors associated with the presence of Toxocara spp. eggs in dog hair. Vet. Parasitol. 2017;244:39-43.

Moawad MA, Amin MM, Hafez EN. Role of Ionizing radiation on Controlling Kidney Changes in Experimental Infection with Toxocara canis. Assiut Vet. Med. J. 2015;61:87-94.

Mojžišová J, Süli J, Goldová M, Bajová V, Švrček Š.The effect of endoparasitism on the immune response to antirabies vaccination in puppies. Acta Parasit. 2007;52:176

Mora M, Veggi D, Santini L, Pizza M, Rappuoli R. Reverse vaccinology. Drug Discov. Today. 2003;8:459-464.

Moreira GMS, de Lima Telmo P, Mendonça M, Moreira ÂN, McBride AJA, Scaini CJ, Conceição FR. Human toxocariasis: current advances in diagnostics, treatment, and interventions. Trends Parasitol. 2014;30:456-464. 
Moorhouse DE. Toxocariasis. A possible cause of the Palm Island mystery disease. Med J Aust. 1982;1:172-173.

Munn EA. Rational design of nematode vaccines: Hidden antigens. Int. J. Parasitol. 1997;27:359-366.

Newton SE, Munn EA. The development of vaccines against gastrointestinal nematode parasites, particularly Haemonchus contortus. Parasitol. Today. 1999;15:116-122.

Nicholas WL, Stewart AC, Mitchell GF. Antibody responses to Toxocara canis using sera from parasite-infected mice and protection from toxocariasis by immunisation with es antigens. Anst. $\mathrm{H}$. Eip. Biol. Med. Sci. 1984;62:619-626.

Nikolić A, Nikolić A, Dimitrijević S, Katić-Radivojević S, Klun I, Bobić B, Djurković-Djaković O. High prevalence of intestinal zoonotic parasites in dogs from Belgrade, Serbia. Acta Vet. Hung. 2008;56:335-340.

Nisbet AJ, McNeilly TN, Wildblood LA, Morrison AA, Bartley DJ, Bartley Y, Longhi C, McKendrick IJ, Palarea-Albaladejo J, Matthews JB. Successful immunization against a parasitic nematode by vaccination with recombinant proteins. Vaccine, 2013;31:4017-4023.

Neill DR, Wong SH, Bellosi A, Flynn RJ, Daly M, Langford TK, Bucks C, Kane CM, Fallon PG, Pannell R, Jolin HE, McKenzie ANJ. Nuocytes represent a new innate effector leukocyte that mediates type-2 immunity. Nature. 2010;464:1367-1370.

Newman MJ, Wu JY, Gardner BH, Munroe KJ, Leombruno D, Recchia J, Kensil CR, Coughlin RT. Saponin adjuvant induction of ovalbumin-specific CD8+ cytotoxic T lymphocyte responses. J. Immunol. 1992;148:2357-2362.

Öge H, Öge S, Özbakış G, Gürcan S. Comparison of Toxocara eggs in hair and faecal samples from owned dogs and cats collected in Ankara, Turkey. Vet. Parasitol. 2014;206:227-231.

O'Hagan DT, Valiante NM. Recent advances in the discovery and delivery of vaccine adjuvants. Nat. Rev. Drug Discov. 2003;2:727-735.

Ooi HK, Lin CL, Wang JS. Effect of ozone treatment on Toxocara canis eggs. J. Vet. Med. Sci. 1998;60:169-173.

Overgaauw PAM. Aspects of Toxocara Epidemiology: Toxocarosis in Dogs and Cats. Crit. Rev. Microbiol. 1997;2:233-251.

Petithory JC, Beddock A. Rôle de Toxocara cati dans le syndrome de larva migrans viscéral. Bull. Soc. Fr. Parasitol. 1997;15:199-211.

Petrovsky N, Aguilar JC. Vaccine adjuvants: Current state and future trends. Immunol. Cell Biol. 2004;82:488-489.

Poulsen CS, Skov S, Yoshida A, Skallerup P, Maruyama H, Thamsborg SM, Nejsum P. Differential serodiagnostics of Toxocara canis and Toxocara cati - is it possible? Parasite Immunol. 2015;37:204-207.

Pratti JES, Ramos TD, Pereira JC, da Fonseca-Martins AM, Maciel -Oliveira D, Oliveira-Silva G, de Mello MF, Chaves SP, Gomes DCO, Diaz BL, Rossi-Bergmann B, Guedes HL. Efficacy of intranasal LaAg vaccine against Leishmania amazonensis infection in partially resistant C57BI/6 mice. Parasit. Vectors. 2016;9:534.
Prociv P. Larval migration in oral and parenteral Toxocara pteropodis infections and a comparison with $T$. canis dispersal in the flying fox, Pteropus poliocephalus. Int. J. Parasitol. 1989;19:891-896.

Rappuoli R. Reverse vaccinology. Curr. Opin. Microbiol. 2000;3:445450.

Reed SG, Hsu FC, Carter D, Orr MT. The science of vaccine adjuvants: advances in TLR4 ligand adjuvants. Curr. Opin. Immunol. 2016;41:85-90.

Regis SCS, Mendonça LR, dos Santos Silva N, Dattoli VCC, Alcântara-Neves NM, Barrouin-Melo SM. Seroprevalence and risk factors for canine toxocariasis by detection of specific $\lg G$ as a marker of infection in dogs from Salvador, Brazil. Acta Trop. 2011;120:46-51.

Roddie G, Stafford P, Holland C, Wolfe A. Contamination of dog hair with eggs of Toxocara canis. Vet Parasitol. 2008;152:85-93.

Santos LN, Pacheco LGC, Pinheiro CS, Alcantara-Neves NM. Recombinant proteins of helminths with immunoregulatory properties and their possible therapeutic use. Acta Trop. 2017;166:202211.

Schabussova I, Amer H, van Die I, Kosma P, Maizels RM. Omethylated glycans from Toxocara are specific targets for antibody binding in human and animal infections. Int. J. Parasitol. 2007;37:97-109.

Schantz PM, Meyer D, Glickman LT. Clinical, serologic, and epidemiologic characteristics of ocular toxocariasis. Am. J. Trop. Med. Hyg. 1979;28:24-28.

Scheibeck R, Pallauf M, Stellwag C, Seeberger B. Elderly people in many respects benefit from interaction with dogs. Eur. J. Med. Res. 2011;16:557-563.

Schoenardie ER, Scaini CJ, Brod CS, Pepe MS, Villela MM, McBride AJ, Borsuk S, Berne ME. Seroprevalence of Toxocara infection in children from southern Brazil. J. Parasitol. 2013;99:537-539.

Sette A, Rappuoli R. Reverse Vaccinology: Developing Vaccines in the Era of Genomics. Immunity. 2010;33:530-541.

Silva MB, Amor AL, Santos LN, Galvão AA, Vera AVO, Silva ES, Barbosa CG, Cooper PJ, Figueiredo CA, Ribeiro R, Alcântara-Neves NM. Risk factors for Toxocara spp. seroprevalence and its association with atopy and asthma phenotypes in school-age children in a small townand semi-rural areas of Northeast Brazil. Acta Trop. 2017;174: 158-164

Singh $M, \mathrm{O}^{\prime}$ Hagan D.Recent advances in veterinary vaccine adjuvants. Int. J. Parasitol. 2003;33:469-478.

Shiny C, Krushna NS, Babu S, Elango S, Manokaran G, Narayanan RB. Recombinant Wolbachia heat shock protein 60 (HSP60) mediated immuneresponses in patients with lymphatic filariasis. Microbes Infect. 2011;13:1221-1231.

Smith KA, Harcus Y, Garbi N, Hämmerling GJ, MacDonald AS, Maizels RM.Type 2 innate immunity in helminth infection is induced redundantly and acts autonomously following CD11c+ cell depletion. Infect. Immun. 2012;80:3481-3489. 
Smith WD, Zarlenga DS. Developments and hurdles in generating vaccines for controlling helminth parasites of grazing ruminants. Vet. Parasitol. 2006;139:347-359.

Soltys J, Borosková Z, Dubinský P, Tomasovicová O, Auer H, Spöck $\mathrm{H}$. Effect of glucan immunomodulator on the immune response and larval burdens in mice with experimental toxocarosis. Appl Parasitol. 1996;37:161-167.

Soriano SV, Pierangeli NB, Roccia I, Bergagna HFJ, Lazzarini LE, Saiz MS, Kossman A, Contreras PA, Arias C, Basualdo JA. A wide diversity of zoonotic intestinal parasites infects urban and rural dogs in Neuquén, Patagonia, Argentina. Vet. Parasitol. 2010;167:81-85.

Sowemimo OA. Prevalence and intensity of Toxocara canis (Werner, 1782 ) in dogs and its potential public health significance in lleIfe, Nigeria. J. Helminthol. 2007;81:433-438.

Sowemimo OA, Lee YL, Asaolu SO, Chuang TW, Akinwale OP, Badejoko BO, Gyange VP, Nwafore T, Henry E, Fan CK. Seroepidemiological study and associated risk factors of Toxocara canis infection among preschool children in Osun State, Nigeria. Acta Trop. 2017;173:85-89.

Sperotto RL, Kremer FS, Berne MEA, de Avila LFC, da Silva Pinto L, Monteiro KM, Caumo KS, Ferreira HB, Berne N, Borsuk S.Proteomic analysis of Toxocara canis excretory and secretory (TES) proteins. Mol Biochem. Parasitol. 2017;211:39-47.

Steinhagen F, Kinjo T, Bode C, Klinman DM. TLR-based immune adjuvants. Vaccine. 2011;29:3341-3355.

Strube C, Heuer L, Janecek E. Toxocara spp. infections in paratenic hosts. Vet. Parasitol. 2013;193:375-389.

Sugane K, Kusama Y, Takamoto M, Tominaga A, Takatsu K. Eosinophilia, IL-5 level and recovery of larvae in IL-5 transgenic mice infected with Toxocara canis. J. Helminthol. 1996;70:153-158.

Symeonidou I, Gelasakis AI, Arsenopoulos KV, Schaper R, Papadopoulos E.Regression models to assess the risk factors of canine gastrointestinal parasitism. Vet. Parasitol. 2017;248:54-61.

Taylor MR, Keane CT, O'connor P, Anthony Girdwood RW, Smith H.Clinical features of covert toxocariasis. Scand. J. Infect. Dis. 1988;1:692-695

Taylor MH, O'connor P, Keane CT, Mulvihill E, Holland C. The expanded spectrum of toxocaral disease. Lancet. 1988;1:692-695.
Torgerson P, Budke C. 2006. Economic Impact of Toxocara spp. In: Holland, C.V., Smith HV. (1st ed) Toxocara The Enigmatic Parasite. CABI Publishing. United Kingdom, Wallingford, pp. 281-293.

Ulanova M. The common vaccine adjuvant aluminum hydroxide up-regulates accessory properties of human monocytes via an interleukin-4-dependent mechanism. Infect. Immun. 2001:69:1151-1159.

Van Kooyk Y, Geijtenbeek TBH. DC-SIGN: escape mechanism for pathogens. Nat. Rev. Immunol. 2003;3:697-709.

Wolfe A, Wright IP. Human toxocariasis and direct contact with dogs. Vet Rec. 2003;152:419-422.

WHO (World Health Organization), 2017. Zoonoses and the Human-Animal-Ecosystems Interface. World Health Organization. http://www.who.int/zoonoses/en/ (search October 20, 2017).

Won KY.National seroprevalence and risk factors for Zoonotic Toxocara spp. infection. Am. J. Trop. Med. Hyg. 2008;79:552-527.

Zahabiu F, Sadjjadi SM, Yunus MH, Rahumatullah A, Moghaddam MH, Saidin S, Noordin R. Production of Toxocara cati TES-120 Recombinant Antigen and Comparison with its T. canis Homolog for Serodiagnosis of Toxocariasis. Am. J. Trop. Med. Hyg. 2015;93:319-325.

Zhou RQ, Ma GX, Korhonen PK, Luo YL, Zhu HH, Luo YF, Gasser RB, Xia QY.Comparative transcriptomic analyses of male and female adult Toxocara canis. Gene. 2017;600:85-89.

Zhu XQ, Gasser RB, Jacobs DE, Hung GC, Chilton NB. Relationships among some ascaridoid nematodes based on ribosomal DNA sequence data. Parasitol. Res. 2000;86:738-744.

Zhu XQ, Jacobs DE, Chilton NB, Sani RA, Cheng NA, Gasser RB. Molecular characterization of a Toxocara variant from cats in Kuala Lumpur Malaysia. Parasitology. 1998;117:155-164.

Zhu XQ, Korhonen PK, Cai H, Young ND, Nejsum P, von SamsonHimmelstjerna G, Boag PR, Tan P, Li Q, Min J, Yang Y, Wang $X$, Fang X, Hall RS, Hofmann A, Sternberg PW, Jex AR, Gasser RB. Genetic blueprint of the zoonotic pathogen Toxocara canis. Nat. Commun. 2015;6:6145. 